\title{
Konstanty Ildefons Gałczyński okiem emigrantów. Rekonesans
}

Streszczenie: Artykuł prezentuje opinie polskich emigrantów o wybitnym poecie polskim Konstantym Ildefonsie Gałczyńskim (1905-1953). Gałczyński w różnych okresach życia zajmował rozmaite pozycje polityczne: przed II wojną był związany z prawicowym pismem „Prosto z Mostu”, po wojnie z ośrodkiem władzy komunistycznej w okresie stalinowskim. Poeta był z tego powodu krytycznie oceniany. Można było założyć, że krytycznie oceni jego postawy polska emigracja niepodległościowa i antykomunistyczna z kręgu Radia Wolna Europa. Jak pokazuje badaczka, jej odbiór poezji i poety był tymczasem prawie wolny od polityki. W Gałczyńskim emigranci widzieli przede wszystkim genialnego poetę.

Słowa-klucze: Konstanty Ildefons Gałczyński, polska emigracja, Radio Wolna Europa, stalinizm, liryzm.

* Anna Janicka - dr hab., prof. UwB; pracuje w Zakładzie Filologicznych Badań Interdyscyplinarnych Uniwersytetu w Białymstoku. Autorka książek: Sprawa Zapolskiej. Skandale i polemiki (Białystok 2013, wyd. 2: Białystok 2015); Tradycja i zmiana. Literackie modele dziewiętnastowieczności: pozytywizm i ,obrzeża” (Białystok 2015). 


\section{Konstanty Ildefons Gałczyński in the eyes of Polish emigration circles. A reconnaissance}

Summary: The article presents the opinions of Polish emigrants about the outstanding Polish poet Konstanty Ildefons Gałczyński (1905-1953). In various periods of his life, Gałczyński held various political positions: before the Second World War he was associated with the rightwing magazine "Prosto z Mostu" [Right off the Bat], after the war with the centre of communist power in the Stalinist period, for which reason the poet was criticised. It could be assumed that his approach would be critically assessed by the Polish independence and anticommunist emigration from the circle of Radio Free Europe. As the researcher shows, her reception of poetry and the poet was actually almost free from politics. Above all, emigrants perceived Gałczyński as a brilliant poet.

Key words: Konstanty Ildefons Gałczyński, Polish emigration, Radio Free Europe, Stalinism, lyricism.

Wróbelek jest mała ptaszyna,
wróbelek istota niewielka,
on brzydką stonogę pochłania
lecz nikt nie popiera wróbelka.

K. I. Gałczyński, O wróbelku $(1947)^{1}$

\section{Wyjaśnienia i pytania}

Na początek rozważań o Gałczyńskim oglądanym okiem XX-wiecznych polskich emigrantów proponuję kilka, zdawałoby się oczywistych, wyjaśnień, zastrzeżeń, usprawiedliwień. Po pierwsze, nie jestem badaczką poezji Gał-

1 K. I. Gałczyński, O wróbelku, cyt. za: tegoż, Liryka i groteska, wybór K. Gałczyńskiej, Warszawa 1980, s. 38. 
czyńskiego, lecz szczególne okoliczności natury czysto naukowej, edytorskiej skłoniły mnie do zabrania głosu w tej sprawie ${ }^{2}$.

Artykuł niniejszy ma więc charakter zarysu, wstępnego sformułowania postulatów badawczych. Siłą rzeczy przedkładam tu zatem więcej pytań niźli odpowiedzi. Pierwsze z nich brzmi na pozór jak truizm: co nam daje uruchomienie glos, głosów, opinii, komentarzy emigracyjnych, formułowanych w listach, artykułach, wspomnieniach, audycjach rozgłośni radiowych, takich jak Radio Wolna Europa?

Można, sądzę, zaproponować następującą odpowiedź: uruchomienie perspektywy emigracyjnej poszerza i na nowo oświetla perspektywę krytyki krajowej, która się wobec emigrantów dystansuje, polemizuje z nimi. Ta konfrontacja dwu stanowisk krytyczno- i historycznoliterackich, epistolograficznych i memuarystycznych otwiera nowe horyzonty, ujawnia wciąż nowe świadectwa, a bywa też, że te już znane - ukazuje w innym świetle.

Wydaje się, iż w odniesieniu do Gałczyńskiego jest to szczególnie ważne - w jego przypadku mamy bowiem do czynienia $\mathrm{z}$ historycznie wytworzoną biografią mityczną (mitobiografią) ${ }^{3}$, osadzoną pomiędzy dwoma kontrapunktami, zantagonizowanymi wobec siebie wektorami oceny. Z jednej strony jest portret idącego na układy z władzą komunistyczną koniunkturalisty, z drugiej równie niebezinteresownego współredaktora bardzo prawicowego przedwojennego pisma „Prosto z Mostu”4. Wydaje się, że do tego układu dodać trzeba jeszcze jedno zakleszczenie Gałczyńskiego - pomiędzy biegunami szlachetnej mitologizacji i brutalnej demitologizacji postaw i dzieł pisarza ${ }^{5}$. Gałczyński

2 Tekst powstał w ramach projektu Narodowego Programu Rozwoju Humanistyki (11H18029286) finansowanego ze środków MNiSW, pod nazwą: „Naukowa, krytyczna edycja z rękopisów w pięciu tomach korespondencji Tymona Terleckiego z Jerzym Giedroyciem, Mieczysławem Grydzewskim, Janem Nowakiem-Jeziorańskim, Kazimierzem Wierzyńskim i innymi”.

3 Zob. A. Makowiecki, Trzy legendy literackie. Przybyszewski, Witkacy, Gatczyński, Warszawa 1980.

4 Por. analizy „prawicowości” i przedwojennych wątków antysemickich u Gałczyńskiego, [w:] K. Nowosielski, Bal u Salomona: salon, Gulistan i Sodoma, „Topos” 2015, nr 4 (143), s. $46-53$.

5 Z ostatnich zabiegów tego typu: M. Wyka, Myśleć o biografii Gatczyńskiego..., „Nowa Dekada Literacka” 2014, nr 3/4; M. Szymański, Nierozwiazana zagadka: biografia Konstantego Ildefonsa Gałczyńskiego, „Tygodnik Powszechny” 2013, nr 47; A. Arno, Niebezpieczny poeta: Konstanty Ildefons Gałczyński, Kraków 2013 oraz R. Gorczyńska, [Niebezpieczny poeta], „Przegląd Polityczny” 2014, nr 123. 
niewątpliwie ma więc legendę i antylegendę, biografię krytyczną i mitobiografię, trudno jednak uciec od przekonania, że są to konstrukcje wyjątkowo oporne na krytyczne wejrzenie; upolitycznione, zsubiektywizowane, czarno-białe, niezbyt obiektywne, pomimo upływu ponad półwiecza od śmierci autora Kroniki olsztyńskiej w 1953 roku.

Żeby właśnie tej dwubiegunowości uniknąć, warto chyba zapytać, jak wybrzmiewa głos o Gałczyńskim z emigracyjnego oddalenia? Dalej: zastanowić się, kto pyta o osobę Gałczyńskiego, a kto analizuje jego twórczość? Trzeba pomyśleć $i$ inną kwestię: czy spojrzenie emigracyjne jest oglądem zdominowanym wszechwładnie przez politykę, czy tylko zapośredniczonym w polityce?

Innymi słowy, pytajmy, czy istnieje jakiś mit/antymit emigracyjny Gałczyńskiego, który zmienia, odkształca, deformuje, przekształca horyzont spolaryzowanych opinii krajowych? Jest to pytanie o to, jak sytuacja emigracyjna profiluje jego twórczość; czy krytyka, memuarystyka, publicystyka emigracyjna wprowadza jakieś nowe fi g u ry poe ty w odniesieniu do dzieła i biografii pisarza? A może wzmacnia lub dekonstruuje stereotypy związane z jego pisarstwem? Temat zda się ogromny, raczej na książkę, niż artykuł analityczny, dlatego ograniczam się tu do sformułowania wstępnych tylko kilku zaledwie opinii o charakterze rekonesansowym.

Jeszcze istotne dopowiedzenia. Wyłączam w niniejszym tekście postać tak ważną, zawieszoną między krajem a emigracją, jak Czesław Miłosz. Nie tylko z powodu Zniewolonego umystu, którego jednym z bohaterów jest Gałczyński. Jest to kwestia osobna, wielekroć już opisywana, chyba też przez samego Miłosza domknięta uznaniem wielkości poetyckiej autora Balu u Salomona: „Co do Delty, umarł w r. 1953, a jego dzieła zebrane są oceniane wysoko"6. Tak

6 Więcej mówi cała wypowiedź Miłosza. Na tle opinii o innych bohaterach Zniewolonego umystu Gałczyński wypada pochlebnie: „Proszę zważyć moje moralne skrupuły: nie jest łatwo napisać un pa mp h l et żyjących ludzi, i jak można być surowym, nie uzurpując dla siebie pozycji sędziego? Pyta mnie Pan o Alfę, Betę, Gammę, Deltę. Dla Alfy mój rozdział o nim był ciosem i być może przyczynił się do jego przemiany. Zmienił się całkowicie. I nie żywi urazy. Przeciwnie, znów jesteśmy przyjaciółmi - na odległość, ponieważ on w przeciwieństwie do innych nie wyjeżdża za granicę. Spróbuję znaleźć dla Pana jedną z jego książek wydanych we francuskim tłumaczeniu. Beta popełnił samobójstwo i dziś uważa się go za jedną z »ofiar stalinizmu«. Dla Gammy moja książka i moja osoba stały się obsesją, nienawidzi mnie i mojemu wpływowi przypisuje wrogość, jaka go teraz w Polsce otacza ze strony innych pisarzy. Co do Delty, umarł w r. 1953, a jego dzieła zebrane są oceniane wysoko". - Th. Merton, Cz. Miłosz, Listy, przeł. M. Tarnawska, Kraków 1991, s. 12-13. 
właśnie Miłosz tłumaczył Tomaszowi Mertonowi w 1959 roku, kim są postaci jego sławnej książki.

Kolejne dopowiedzenie - skupiam się na środowisku związanym z Radiem Wolna Europa, jego audycjach, felietonach, słuchowiskach, wspomnieniach. Szczególnie - doprecyzujmy - będzie mnie interesował punkt widzenia Czesława Straszewicza (1904-1969), a w końcu kompozytora i publicysty Romana Palestra (1907-1989), który, o dziwo, czytał Gałczyńskiego właśnie politycznie, a nie muzycznie czy muzykologicznie. Zdaję sobie przy tym sprawę z polifonii poglądów i postaw politycznych, estetycznych, filozoficznych emigracji londyńskiej, paryskiej czy monachijskiej, rzutującej na ocenę poszczególnych zjawisk krajowych. Zjawisk wymykających się, jak autor Zielonej Gęsi, prostym ocenom, zaszufladkowaniom.

I kwestia zasadnicza, fundamentalna - pytanie, czy to polityka jest czynnikiem kreującym obraz Gałczyńskiego oglądanego sub specie emigracji z horyzontu wolnej, zachodnioeuropejskiej demokracji?

\section{Gałczyński okolicznościowy i sytuacyjny}

Na początek pytanie natury ogólnej - trzeba je tu postawić. Jak w eterze, na falach RWE, obecny jest Gałczyński? Jak jego poezja jest tu prezentowana? W jakich okolicznościach - i szczególnie - w jakich osobowych i estetycznych konfiguracjach pojawiają się: poeta i jego liryka? Czy tylko liryka?

Wysłuchałam kilkudziesięciu radiowych audycji ${ }^{8}$, słuchowisk, felietonów $\mathrm{z}$ autorem Niobe w roli głównej bądź w tle, co pozwala wskazać (i tylko wskazać, podkreślam, a nie ogłosić ex cathedra) kilka wstępnych rozpoznań na temat obrazu Konstantego Ildefonsa Gałczyńskiego na falach Radia Wolna Europa w latach od 50. do 90. XX wieku.

Zacznijmy od przywołania kilku przykładów audycji RWE z Gałczyńskim w roli głównej bądź epizodycznej:

- 20-lecie szkoły im. Stefana Żeromskiego w Londynie, 1 stycznia 1970 (data emisji). Tu między innymi: Pieśń o fladze Gałczyńskiego.

7 Por. opinie o relacji Miłosz - Gałczyński: Z. Kaźmierczyk, Poeta upojeń - Gałczyński w oczach Miłosza, „Topos” 2015, nr 4 (143), s. 64-70.

8 Można ich wysłuchać w cyklu Radia Wolności Polskiego Radia: https://www.polskieradio.pl/68/787/Tag/27742 [dostęp: styczeń 2019 r.]. 
- Audycja muzyczna: Pieśń dla żotnierzy Westerplatte; kompozycja Ireny Pfeiffer z tekstem Gałczyńskiego (wykonuje chór męski „Bart”). Dalej: List z oflagu - kompozycja Jana Maklakiewicza z tekstem Gałczyńskiego.

- V Rocznica Pontyfikatu Jana Pawła II. Emisja: 23 października 1983. Jest to relacja z uroczystego wykonania Te Deum z okazji pięciolecia pontyfikatu Jana Pawła II w kościele św. Jerzego w Monachium. Recytowane wiersze: Bogurodzica, Litania lwowska (K. Wierzyński), „Matko, Tyś naród polski”, pieśń „Panienko Ty nasza” (S. Wyspiański), Modlitwa za pomyślny wybór papieża Gałczyńskiego, Widzenie z III cz. Dziadów Mickiewicza, wiersz Pośród niesnasek... Juliusza Słowackiego, także utwory religijne (Chrystus wodzem), Myślac ojczyzna, Tworzywo (1956) Karola Wojtyły.

Jak widać, pisarz pojawia się $\mathrm{w}$ - przyznajmy: zaskakującej - konfiguracji poetów narodowych, wieszczów, między Bogurodzica, Mickiewiczem a utworami Wojtyły. Patriotyczny i martyrologiczny kontekst usuwa na bok jakiekolwiek polityczne aluzje, niedopowiedzenia. Gałczyński jawi się tu jako patriota, a nawet więcej - poeta polskiego losu.

Dopełnieniem tej strategii przywoływania poezji Gałczyńskiego jest inna - o nieco wyciszonej tonacji patetycznej - ukazująca go jako poetę świąt i polskiej codzienności. Takiego liryka znajdziemy w audycjach:

- Księżyc w twoim oknie (emisja: 26 grudnia 1963); słuchowisko Jana Kruka-Paszkowskiego, w którym recytowano fragmenty wierszy Gałczyńskiego i Wierzyńskiego 9 .

- Muzyka i pieśni wielkanocne (emisja: 3 kwietnia 1983); audycja w opracowaniu Toli Korian. W audycji można było wysłuchać Alleluja, pieśni pasyjnych wenezuelskich, serbskich i recytacji wiersza Gałczyńskiego Zebrały się wróble na drzewie. W zmienionej wersji tejże audycji można było wysłuchać także fragmentów oratorium Mesjasz Haendla, Alleluja Mozarta i Rezurekcji Bronisławy Ostrowskiej.

- Boże Narodzenie w poezji Konstantego Ildefonsa Gałczyńskiego (emisja 24 grudnia 1988 roku). Wiersze interpretują tu Barbara Nawrotowicz i Bogusław Jarke: Na kołysce kogut złoty, Było, uważacie, pięćdziesięciu studentów.

9 Wykonawcy: Jan Krok-Paszkowski; Janina Radulska; Jerzy Bożekowski; Jerzy Kopczewski; Irma Zembrzuska; Wojciech Wojtecki. W audycji wykorzystano m.in. Koncert fortepianowy Konstantego Ildefonsa Gałczyńskiego i Podjudzanie księżyca Kazimierza Wierzyńskiego. 
Jak widać, Gałczyński wchodzi na emigracji w przestrzeń przeznaczoną dla poetów/twórców religijnych, metafizycznych ${ }^{10}$. Związek poety ze sferą sacrum - tylko na podstawie jego wierszy - wydaje się autorom emigracyjnych słuchowisk naturalny i oczywisty ${ }^{11}$. Znów: jakże daleko tu od wszelkich polityczno-ideologicznych kontekstów bieżących. Choć, co też oczywiste, przywoływanie poezji Gałczyńskiego w narodowo-religijnym kontekście jest wyraźnym wpisaniem tej twórczości w wizję świata emigracji powojennej: wizję antykomunistyczną, demokratyczną, patriotyczno-religijną. Lecz to tylko ogólny, jakby naddany kontekst audycji, które miały nade wszystko wywoływać i wzruszenie, i emocje, i wspomnienia.

Zaraz po tych - patriotycznej, świątecznej, lirycznej - inkarnacjach pojawia się na emigracji Gałczyński jako - tylko i aż! - po prostu poeta. Taki obraz prezentuje Pochwata poety (emisja: 28 lutego 1960), radiowy felieton Kazimierza Wierzyńskiego. Jego autor, także przecież pisarz, syntetyzuje w felietonowym oglądzie całość życia i twórczości Gałczyńskiego. Jeszcze do tej audycji wrócimy.

Jednakże obok tej poważnej wizji pojawia się inna: wzniosły autor Pieśni prezentowany jest na falach RWE jako twórca filuterny, witalny, frywolny, balansujący między postawą narodowo-wzniosłą a postawą facecjonisty, twórcy fraszek i lirycznych błahostek (o wielkim ciężarze egzystencjalnym, będących dla emigrantów konsolacją, swoistą ucieczką od trosk emigracyjnej codzienności). Trzeba tu przywołać dwa słuchowiska: Idzie wiosna z 27 marca 1989 roku z wierszami Wierzyńskiego i Gałczyńskiego oraz Piękna płeć na cenzurowanym z 2 stycznia 1972 roku. Ta druga audycja to słuchowisko Marii Pruszkowskiej, oparte na fraszkach polskich (od mistrzów renesansowych Mikołaja Reja i Jana Kochanowskiego, poprzez Bartosza Paprockiego, Jana Andrzeja Morsztyna, Wacława Potockiego i Ignacego Krasickiego aż po Tadeusza Wittlina,

10 O subtelnej różnicy pomiędzy poezją religijną i metafizyczną zob. między innymi: K. Jarzyńska, Między tropieniem sacrum a postsekularyzmem. O badaniu religijnych aspektów dzieła Czesława Miłosza, „Świat i Słowo” 2015, nr 2 (25) oraz K. Dybciak, Literatura polska XX wieku wobec religii, Kraków 2005.

11 Właściwie do podobnych wniosków dochodzą współcześni badacze metafizycznego wymiaru poezji Gałczyńskiego. Zob. J. S. Ossowski, Szarlatanów nikt nie kocha. Studia i szkice o Gałczyńskim, Kraków 2006; Konstanty Ildefons Gałczyński znany i nieznany. Studia i szkice, red. A. Gomóła, Katowice 2005 oraz Dzieło i życie Konstantego Ildefonsa Gałczyńskiego, red. A. Kulawik, J. S. Ossowski, t. 1-2, Kraków 2005. 
Jana Sztaudyngera, Marię Buyno-Arctową, Tadeusza Boya-Żeleńskiego, Jana Paczkowskiego i, oczywiście, Gałczyńskiego).

Uzupełnieniem tego konterfektu może być obraz Gałczyńskiego jako sentymentalnego flaneura poezji krajowej zaprezentowany w audycji Warszawskie ulice w pieśni i piosence wczoraj i dziś (emisja: 25 grudnia 1974) ${ }^{12}$.

W końcu pojawia się także Gałczyński osadzony we wspomnieniach, anegdocie, emigracyjnych biografiach, jak we wspomnianej już Pochwale poety Wierzyńskiego z 1960 roku. Last but not least znajdziemy też obraz Gałczyńskiego jako przykład politycznej wolności w sytuacji politycznej podległości, jak w felietonie politycznym Komentarz dnia Romana Palestra z 24 stycznia 1954 roku. Jest to audycja, czego nie można przeoczyć, stworzona krótko po śmierci poety, naznaczona mocno niejednoznacznymi echami quasi-politycznych wyborów autora Pieśni.

Jak więc zauważamy, Gałczyński jest na emigracji obecny konsekwentnie i, co zadziwiające, jednoznacznie. Nie jest tu postacią ze Zniewolonego umystu Miłosza, reżimowym wajdelotą czasów stalinizmu, ale poetą po prostu, urodzonym lirykiem, który w najlepszych chwilach swego poetyckiego żywota tworzy dzieła nieprzemijające, co więcej, dzieła naznaczone patriotyczną i religijną wymową. Autor Wita Stwosza bywa, owszem, pisarzem-człowiekiem o ambiwalentnej biografii, lecz jeszcze bardziej niż tę ambiwalencję eksponuje się jego legendotwórcze gesty - trochę błazna, trochę tragika. Pomiędzy biegunami satyry, fraszki, żartu i wzniosłości ujawniają emigranci obraz poety, który jest dla nich bezdyskusyjnym klasykiem, mistrzem polszczyzny, humorystą i tragikiem.

Taki Gałczyński wyraża r o z p a c z pols ki e g o los u, który, zawieszony między skrajnymi wyborami politycznymi, powinien był go przygnieść, wprawić w liryczną niemotę ${ }^{13}$. A tymczasem Gałczyński w czasach marnych

12 W audycji wykorzystano fragmenty utworów poetyckich Artura Oppmana, Konstantego Ildefonsa Gałczyńskiego (m.in. Warszawski wiatr), Tadeusza Różewicza, Antoniego Langego i Kazimierza Wierzyńskiego. Wykonawcy piosenek: Irena Santor, Sława Przybylska, Barbara Rylska, Mira Zimińska, Stanisław Grzesiuk, Jarema Stępowski i Karol Marek. Wykonawcy wierszy: Bogusław Jerek i Janusz Marchwiński.

13 Por. opinię córki pisarza, Kiry, tłumaczącą powojenne wybory Gałczyńskiego: „K G. Myślę, że wojna i wszystko, czego doznał i co działo się wokół niego, wstrząsnęło podstawową zasadą jego bytowania, a więc i sztuki, dla której żył, którą kochał ponad wszystko. Wojna z jej makabrycznymi następstwami miała tę sztukę zniszczyć, a także miała zburzyć coś, co 
pisze genialne wiersze w sposób nieporównywalny z niczym, wyrażające los i krajowców, i emigrantów. Ma swój poetycki idiolekt, który emigracja nie tylko docenia, ale uznaje za jedyny w swoim rodzaju. Inna rzecz, że poezji tej nie mogą emigranci oderwać od postaci samego poety - to przecież ich kolega, którego prowokacje, upadki, błazeństwa, ucieczki doskonale pamiętają. Pomimo „wszystko”, jest dla nich wielki.

\section{Trzy wcielenia}

Z wielu głosów o Gałczyńskim wybieram - tytułem egzemplifikacji - trzy: Czesława Straszewicza, Kazimierza Wierzyńskiego i Romana Palestra.

Historia o lasce ze srebrna gatka została nadana przez RWE 29 marca 1959 roku jako audycja z cyklu „Program Specjalny” Polskiej Sekcji Radia Wolna Europa $^{14}$. Był to dwugłos Ryszarda Dzikowskiego i Czesława Straszewicza, przybyłego właśnie na kilka lat z „urugwajskiego wygnania”15 do Monachium, gdzie znalazł zatrudnienie w rozgłośni. Uprawiał Straszewicz rozmaite formy radiowe - od bieżącego komentarza politycznego, poprzez słuchowisko historyczne, aż po gawędy radiowe i wspomnienia ${ }^{16}$. Jakim wspomnieniem o Gałczyńskim podzielił się ze słuchaczami?

Nazwałabym je serdecznym, choć też podszytym wyraźnie ironią. Jest to wszakże ironia osobliwa, bo czuła, nieką́liwa, wyważona, subtelnie zniuansowana. Widać, iż wspominający ucieka od kontekstów politycznych, lecz też od poezji, w stronę anegdoty, czasu przeszłego. Wyłania się z tego zapisu portret Gałczyńskiego czule osobliwy i wybitnie osobny, nieporównywany z żadnym innym konterfektem pisarskim (Hłasko, Gombrowicz). Tu konieczny jest dłuższy cytat:

w sobie wypracował od dziecka: zaufanie do drugiego człowieka. Bo człowiek, istota może nie najdoskonalsza, ale przewidywalna, ma w sobie i szlachetność, i pewną mądrość, i potrzebę kochania. A to wydobywa i pogłębia sztuka. I dlatego nie może zabijać, nie może niszczyć, nie może rugować myśli sprzed setek lat. I nagle to wszystko mu się zawaliło: było dokładnie inaczej. Człowiek mógł zabijać, mógł niszczyć, mógł wymazywać starą myśl sprzed stuleci. To równało się z próbą zabicia sztuki. A na to nie mógł pozwolić”. - W oczekiwaniu na najwyższy ton, z Kira Gałczyńska - pisarka i córka K. I. Gałczyńskiego - rozmawia Wojciech Kass, „Topos” 2015, nr 4 (143), s. 35.

14 V. Wejs-Milewska, Archiwum radiowe Czestawa Straszewicza. „Historia o lasce ze srebrną gatka...”, ,Kresy” 2001, nr 3, s. 237.

15 Tamże, s. 236.

16 Tamże. 
„Ryszard Dzikowski: Gałczyński po śmierci zdaje się ma nieprzebrane morze przyjaciół na świecie?

Czesław Straszewicz: Nawet nie wiem, czy ja byłem przyjacielem Gałczyńskiego. Miał lepszych zapewne. Poznałem go po raz pierwszy w Kole Polonistów na Uniwersytecie Warszawskim, gdy w tym swoim zielonym, nieśmiertelnym krawacie, podszedł do mnie nieznajomego i rzekł: Dajcie mi pięć złotych na wódkę! Żeby mi powiedział: »pożyczcie«, pewno bym nie dał. Ale tak - dałem. A potem przez kilka ładnych uniwersyteckich lat, byłem świadkiem i uczestnikiem tych wszystkich hec, o których jak najtrafniej opowiedzieli już inni »przyjaciele« Gałczyńskiego.

Ryszard Dzikowski: O ile mnie pamięć nie myli, Gałczyński i pan byli filarami tygodnika »Prosto z Mostu«, więc ostatecznie musieliście się od czasu do czasu trącać łokciami. Tak samo Jerzy Andrzejewski był w »Prosto z Mostu«, Jerzy Walldorf. Jak ktoś, kiedyś dowcipnie napisał, »niezła stajnia«. Wracając zatem do Gałczyńskiego...

Czesław Straszewicz: Ciągnie mnie pan za język akuratnie... Gałczyński był straszny dla otoczenia człowiek. Miał to do siebie, że wpinał się w każdego jak kleszcz. Przypominał mi również »Wańkę-wstańkę«. Co się położył, już był na nogach. Do końca życia wspomnienie o nim związało mi się z »laską ze srebrną gałkąu.

\section{Ryszard Dzikowski: O!}

Czesław Straszewicz: Za czasów studenckich byłem na wycieczce w Konstantynopolu. Jako nieco romantyczny młody człowiek, kupiłem sobie na tureckim bazarze trzcinową laskę, w której kryło się ostrze »kutej w Damaszku« szpady. Laska miała na rączce srebrne okucie. Wróciwszy do Warszawy, paradowałem z tą laską po Uniwersytecie, bardzo dumny. Przy różnych okazjach i bez okazji - ot jak ten szczeniak - w Kole Polonistów i w Kole Filozoficznym, i na zebraniach Sekcji Twórczości Własnej - przed Aleksandrem Maliszewskim, przed Stanisławem Ryszardem Dobrowolskim, przed Hanką Huszczówną, przed Gałczyńskim - obnażałem tę szpadę. Dorobiłem przy tym historię, że szpada owa, ukryta obecnie w lasce, bo ja wiem, nie twierdzę, ale kto wie (jak mówił na bazarze sprzedawca), należała kiedyś do Gotfrieda de Bouillon...

Ryszard Dzikowski: Ale pan zaiwaniał, panie Czesławie! Zaiwaniał pan, aż się kurzyło... 
Czesław Straszewicz: - Zaiwaniałem. Ale wie pan kto to połknął? Gałczyński! Nie powiem, że uwierzył, ale mu się podobało. Napisał nawet o tej lasce wiersz.

Ryszard Dzikowski: Nie czytałem.

Czesław Straszewicz: Wielu wierszy Gałczyńskiego pan nie czytał. W tych czasach przedwojennych uchodziłem za zamożniejszego od innych. Nie była to całkiem prawda, ale Gałczyński... Chwileczkę! Wie pan, jak wyglądał mój bruderschaft z Gałczyńskim?

Ryszard Dzikowski: Świadkiem nie byłem...

Czesław Straszewicz: Już za czasów »Prosto z Mostu« spotkałem się kiedyś, nie pamiętam już przy jakiej okazji, w ówczesnym barze »Polonia« ze »srebrną Natalią« i z »zielonym Konstantym«. Było to w porze obiadowej, wypiliśmy coś, przekąsili, no i buzi - buzi. Wracam do mamy na Polną, nie mija piętnaście minut, telefon: Tu Konstanty. Czesław czy nie mógłbyś mi pożyczyć dwudziestu złotych?

Ryszard Dzikowski: Pierwsze słowa na »ty«?

Czesław Straszewicz: Pierwsze słowa na »ty«. Ale nie o tym chciałem mówić. Gałczyński za każde pożyczone dwadzieścia złotych dawał mi wiersz. - Odbierzesz sobie kiedyś z procentem - mówił za każdym razem. Uzbierałem tego obfity portfel. Między innymi znajdował się wiersz o lasce ze srebrną gałką. Portfel był z żółtej skóry i farbował. Pamiętam, że te wszystkie bibułki z wierszami Gałczyńskiego były zafarbowane na żółto...

Ryszard Dzikowski: Ma pan te wiersze?

Czesław Straszewicz: Wojna, panie, wojna! Oczy moje nie widziały tego żółtego portfela od czasu wojny. Przepadł.

Ryszard Dzikowski: Prawda, zapomniałem, pan przecież na kilka miesięcy przed wojną wyjechał razem z Gombrowiczem do Ameryki Południowej?

Czesław Straszewicz: Daj mi pan dokończyć historię o lasce ze srebrną gałką. Był okres, że jeździłem do Gałczyńskich do Anina, a oni oboje, albo on sam, przychodzili do mojej mamy na Polną. Był to jego okres, w którym improwizował fascynujące rzeczy o Anglii. Otóż, poza tymi spotkaniami w »Ziemiańskiej«, w Aninie i na Polnej, były jeszcze spotkania ekstra. Gdzieś o czwartej lub piątej nad ranem: telefon! Telefon dzwoni i dzwoni, podchodzę wściekły: kto mówi? - Długa, ponura cisza. Wreszcie glos jak ze studni: 
- Konstanty! - Czego chcesz u diabla!? - Jeszcze bardziej ponura cisza. - Co z tobą, Kostek? Co się stało? - Bierz natychmiast taksówkę - mówi grobowy głos - i przyjedź do baru na Bielańskiej, na Plac Teatralny. - Po co? - Znowu cisza. Po chwili: Jestem bez forsy! - Kostek - mówię zły - jest noc, ja śpię, każ się wypchać i pomalować na zielono! - Złowroga cisza. A potem bardzo smutne, bardzo żałosne, bardzo przejmujące: - Czesławie, Czesławie, gdzie jest twoja laska ze srebrną gałką?

Ryszard Dzikowski: Co w tym wypadku laska miała do rzeczy?

Czesław Straszewicz: Widzi pan, ta laska ze srebrną gałką zginęła mi jakoś kilka lat przedtem, a może mi ją ktoś świsnął. Gałczyński dobrze tę laskę zapamiętał i uważał ją niejako za symbol młodości i fantazji, ile razy coś mu się we mnie nie podobało, zwalał to na karb tej laski, która zginęła.

Ryszard Dzikowski: I pojechał pan w nocy do tego baru na Bielańskiej?

Czesław Straszewicz: Pojechałem. Co później się zwykle działo, szkoda gadać, bo »seansy« Gałczyńskiego trwały po kilka dni bez przerwy, bez wytchnienia. Gałczyński był silny jak byk. Po wojnie nie byłem tak skonany, jak po Gałczyńskim.

Ryszard Dzikowski: Z tego wniosek, że Hłasko to mięta?

Czesław Straszewicz: Nie powiedziałbym. Każdy ptak ma swoje piórka...

Ryszard Dzikowski: A Gombrowicz?

Czesław Straszewicz: To znowu inna para kaloszy (...)"17.

Gałczyński Straszewicza jest postacią o nader silnej osobowości, swego rodzaju histrionem, człowiekiem i słabym, i mocnym. To osobowość uzależniona od pozy, gry i kontestacji tej własnej pozy i gry, lecz zarazem na swój sposób wielka. Jest w tym głosie też rys niepoznawalności fenomenu, jakim był autor Zielonej Gęsi. Trochę geniusz, trochę łotrzyk, urwis, skandalista, Gałczyński nie dawał się ująć w jakąkolwiek formułę. Warto zauważyć, że anegdota „pożera” tu wszelkie konteksty polityczne („Prosto z Mostu”, prawica, antysemityzm, stalinizm, reżimowość etc.). Mitobiografia i geniusz liryka zwyciężają pozostałe konteksty opowieści o poecie-micie. 
W zupełnie inną stronę idzie - we wcześniejszej zresztą audycji - Roman Palester ${ }^{18}$. Interesuje go właśnie Gałczyński w politycznej koterii socrealistów. Ale tu - o dziwo! - poeta ten staje się uosobieniem niezależności; kimś, kto dzięki genialności swego poetyckiego słowa funkcjonuje w systemie politycznej opresji, lecztego systemu nie uwewnętrznia. Przykładami przeciwnymi - politycznego uwewnętrznienia systemu - stają się w ocenie felietonisty: Jarosław Iwaszkiewicz, Zofia Nałkowska, Antoni Słonimski. Przywołajmy początek wypowiedzi Palestra: „Ciosy, jakie ostatnio spadły na literaturę polską - śmierć Gałczyńskiego i Tuwima - dały okazję do całego szeregu artykułów i wypowiedzi pisarskich" ${ }^{19}$. Zanim Palester zanalizuje nowomowę tych tekstów (głównie pióra Wiktora Woroszylskiego), doda bez wątpliwości i wahań:

„Jeśli chodzi o dwóch zmarłych poetów - najwybitniejszych pomiędzy tymi, którzy pozostali w kraju - to ich przeszłość była dla »koncesjonowanych « krytyków partyjnych ambarasującym orzechem do zgryzienia. Niełatwo było sobie poradzić z sanacyjno-patriotyczną przeszłością Tuwima, podobnie jak z ONR-owską Gałczyńskiego. Ale ponieważ w systemie komunistycznym nie wolno czcić samej poezji bez dokładnego zanalizowania i partyjnego »zatwierdzenia« tak zwanego światopoglądu autora, zatem trzeba było wiele wierszy przemilczeć, wiele faktów przekręcić, wiele wystąpień zmarłych poetów przedstawić w fałszywym świetle"20.

Kompozytor-publicysta ustala więc własną hierarchię wewnętrznej niezależności i, jak widać, w hierarchii tej Gałczyński wraz z Tuwimem zajmują miejsce pierwszorzędne, uciekają systemowi:

„Ale jest inna linia [niż zaprzedania talentu na usługi komunistycznej deprawacji], linia tragicznego podziału między człowiekiem a straszliwym systemem ucisku, linia podziału między milionami gnębionych i uciskanych a garstką uciskających, między przygniatającą większością Polaków a wąttym gronem sprzedawczyków"21.

18 R. Palester, Bolaczki ostatniego dziesięciolecia [Komentarz dnia/615, 24 stycznia 1954], cyt. za: V. Wejs-Milewska, Radio Wolna Europa na emigracyjnych szlakach pisarzy: Gustaw Herling-Grudziński, Tadeusz Nowakowski, Roman Palester, Czesław Straszewicz, Tymon Terlecki, Kraków 2007, s. 563-566.

19 R. Palester, dz. cyt., s. 563.

20 Tamże, s. 563.

21 Tamże, s. 565. 
Zarówno Gałczyńskiego, jak i Tuwima sytuuje Palester po właściwej stronie. Znamienne, iż jest to głos z 1954 roku, kiedy na Gałczyńskiego patrzono w kraju z podejrzliwością; poświęcony poecie rozdział (Delta - czyli trubadur) Zniewolonego umystu Miłosza funkcjonował już wtedy w przynajmniej siedmiu wielojęzycznych wydaniach ${ }^{22}$. Palester zdobył się w tych okolicznościach na głos całkowicie niezależny, czemu, jak by mogło się z pozoru wydawać, nie sprzyjała perspektywa antykomunistycznie nastawionego emigranta.

Te dwie perspektywy - anegdotyczną i wartościująco-wspomnieniową scala niejako felieton poświęcony Gałczyńskiemu autorstwa Kazimierza Wierzyńskiego zatytułowany Pochwała poety (data emisji: 28 luty 1960 roku) ${ }^{23}$. Punktem wyjścia czyni Wierzyński własną lekturę trzech pierwszych tomów, z pięciu zapowiedzianych, dzieł zbiorowych Gałczyńskiego ${ }^{24}$. To właśnie ta skupiona lektura staje się impulsem do refleksji o „niedoczytaniu” Gałczyńskiego. Bierze się ono z dwu źródeł. Primo, z biografii, która przesłoniła dzieło; secundo, z własnej pamięci, która zbudowała dystans wobec kłopotliwego poety. Wierzyński oznajmia: „Nie mogłem się jakoś zbliżyć [do poety] za życia, teraz w skupieniu czytam dzieła”25. „Teraz”, czyli w momencie, kiedy w przeszłość odchodzi biografia „,spoconego kirusa”, „bełkotliwego pijusa”. Ale też „teraz”, kiedy już zostaje tylko słowo wybitnego poety. Pojawia się w felietonie wyraźny postulat, by nie czytać tej poezji przez biografię, bo wówczas zawsze zostajemy zniesieni na interpretacyjne mielizny przez biografię nadmiernie wybujałą.

Ustaliwszy więc własną perspektywę, Wierzyński przystępuje do oceny wydanych właśnie dzieł zebranych, respektując chronologiczny porządek tegoż wydania. Ów układ wydaje mu się ambiwalentny. $Z$ jednej bowiem strony, tak „ułożona” liryka niepotrzebnie wciąga czytelnika w „chaos życiowy poety" ${ }^{26}$. Z drugiej strony, chwali decyzję edytorów, bowiem oglądana chro-

22 Zniewolony umyst (1953) ukazał się do 1956 roku po angielsku (trzy razy), francusku, niemiecku, hiszpańsku, włosku, szwedzku.

23 K. Wierzyński, Pochwała poety (https://www.polskieradio.pl/68/2461/Audio /298498,Pochwala-poety).

24 K. I. Gałczyński, Dzieła zebrane, t. 1-5, Warszawa 1957-1960. Por. też pracę doktorską Olimpii Gogolin, Polskie edycje książkowe dzieł Konstantego Ildefonsa Gałczyńskiego z lat 1929-2010, Katowice 2014 [Repozytorium UŚ].

25 Tamże.

26 Tamże. 
nologicznie twórczość Gałczyńskiego odsłania rdzeń jego świata poetyckiego, „werwę życia”. U tak czytanego poety ,życie wre”27. Gałczyński jest dla Wierzyńskiego nade wszystko poetą wyobraźni dynamicznej, „niezmąconej ruchliwości fantazji”, z której płynie to, co stanowi o wyjątkowości talentu - humor, ironia, groteska. Humor osobliwy, niepowtarzalny, bo oscylujący między „szubienicznym śmiechem” a „pogodnym uśmiechem najczystszego wzruszenia lirycznego". Czasami tylko, wskazuje Wierzyński, muza poety osuwa się w czeluść groteski, lecz nawet wtedy jest to groteska oryginalna „à la Chagalle”28, łącząca beztroskę z tragifarsowością istnienia. To połączenie figur niełączliwych u poety wybitnego daje pożądany efekt pure nonsensu, który z kolei ocala go jako człowieka.

Ocala też jako poetę - uwięzionego w ideologicznej klatce, ale $\mathrm{z}$ nią nie zrośniętego.

Przy czym, co ważne, owa poza szarlatana nie wyklucza postawy filozofa. Na zarzut, że Gałczyński za mało eksperymentuje z formą, Wierzyński odpowie błyskotliwą ripostą: „Nie ma innej now ości niż talent”29. Ten zaś nigdy się w poezji prawdziwej nie wyczerpuje, podczas gdy eksperymentatorstwo kończy się prędzej czy później banałem, „osuwa się w banał, bo staje się regułą" ${ }^{30}$. Dla Wierzyńskiego, poety też przecież wybitnego, Gałczyński nie jest poetą reguly, jest poetą wyjątku. Wyjątku, dodajmy, potwierdzanego każdym wierszem.

Konkludując - liryka Gałczyńskiego to dla autora Lauru olimpijskiego ,jedyna żywa poezja na [zniewolonej-A. J.] ziemi polskiej”31. Poezja, za którą liryk płacił cenę; i to ceną wysoką.

$*$

Konterfekt Gałczyńskiego, jaki ujawnia twórczość powojennych emigrantów, zaskakuje przede wszystkim oderwaniem od bieżących wyborów politycznych, ideowych poety, od kontekstu doraźnej walki stronnictw. Autor

$\begin{array}{cc}27 & \text { Tamże. } \\ 28 & \text { Tamże. } \\ 29 & \text { Tamże. } \\ 30 & \text { Tamże. } \\ 31 & \text { Tamże. }\end{array}$ 
Pieśni to tutaj pisarz strasznej epoki, nierzadko z własnej winy pozwalający zamknąć się w klatce ideologii tak przeciwnych, jak nacjonalizm endecki i stalinizm, ale nigdy nie przejmujący tych idei. Poeta ten zachowuje bowiem wolność wewnętrzną - nade wszystko jako genialny liryk i humorysta, którego nie są w stanie zbałamucić ani pochłonąć żadne ideologie.

Nie ma w opiniach emigrantów - przynajmniej tych tu przywoływanych z kręgu RWE - krytyki z pozycji politycznych. Znajdziemy tu za to anegdotę, pokazującą Gałczyńskiego jako skandalizującego szaławiłę, ale też w głębi duszy tragika. Zdumiewają patriotyczno-religijne przywołania jego wierszy, ale też nawiązania do jego humorystyki. W każdym z wcieleń jest Gałczyński od 1954 do 1989 roku dla emigrantów - klasykiem poezji polskiej.

Po prostu - wielkim poetą wielkiego talentu.

\section{Bibliografia}

Bujnicki T., O „smorgońskim" skeczu "Związek Zawodowy Literatów”, „Napis" 2002/ nr VIII.

Dzieło i życie Konstantego Ildefonsa Gałczyńskiego, red. A. Kulawik, J. S. Ossowski, Kraków 2005.

Helman Z., Roman Palester - kompozytor i intelektualista, „Archiwum Emigracji” 2015, z. 1/2.

Kass W., Gałczyński urzeczony, „Topos” 2015, nr 4 (143).

Kulawik A., Poezja to jest złoty szerszeń. Rzecz o poematach K. I. Gałczyńskiego, Kraków 2015.

Merton Th., Miłosz Cz., Listy, przeł. M. Tarnowska, Kraków 1991.

Ossowski J. S., Szarlatanów nikt nie kocha. Studia i szkice o Gałczyńskim, Kraków 2006.

Studia o twórczości Kazimierza Wierzyńskiego, pod red. J. Opackiego, współudział R. Cudak, Katowice 1986.

Wejs-Milewska V., Archiwum radiowe Czesława Straszewicza, „Kresy” 2001, nr 3. Wejs-Milewska V., Rzeczy teatralne: Tymon Terlecki w londyńskim studiu Radia Wolna Europa, „Pamiętnik Teatralny” 2011, z. 3/4. 